\title{
Explanation and Analysis of the Reasons of Occurring Sedition in Kalila and Dimna
}

\author{
Mohammad Khodadadi*, Mohammadali Gozashti \\ Department of Persian Language and Literature, Islamic Azad University Central Tehran Branch, Tehran, Iran \\ Corresponding Author: Mohammad Khodadadi, E-mail: khoda13932014@gmail.com
}

\section{ARTICLE INFO}

Article history

Received: February 12, 2017

Accepted: August 23, 2017

Published: August 07, 2017

Volume: 8 Issue: 4

Advance access: August 2017

Conflicts of interest: None

Funding: None

\begin{abstract}
Sedition is one of the political and social disorders in humankind societies. In case of occurring sedition, a society will involve in not only disturbance and chaos, but also it is possible to destroy the political system, so this factor is considered as severe threaten from creation and forming the political systems up to now. Most of the scientists considered the valuable book of Kalila and Dimna as political constitution which was written by Nasrollah Monshi and this important factor was expressed in different dimensions as evidenced by this statement. In this Article, it is attempted to be involved in explanation and analysis of the reasons of occurring the sedition such as jealousy, greed and avidity, aversion, pride and revenge in Kalila and Dimna.
\end{abstract}

\section{Key words:}

Kalila and Dimna,

Sedition,

Jealousy,

Greed and Aversion

\section{INTRODUCTION}

The word "Sedition" has plenty usage in our colloquial literature and culture and this word has several meanings and every person uses it in proportion to his viewpoint and understanding.

It has opulent usage in several concepts not only its multilateral review in Islamic culture and society is necessary, but also necessity of its review will show itself more in literary texts.

Since, the Persian literary prose texts show this natural and justified factor from beginning times of its writing as well with regard to the issues and events occurred in that time and its natural and evident process in current centuries and eras.

The original book of Kalila and Dimna, named "Panchatantra" was written in five chapters by Nasrollah Monshi in Indian and Borzoyeh Tabib Morouzi in the era of Anoshirvan Khosrow, son of Qobad, Sassanid King translated it in Persian and added several narratives and stories to it that the most of them was from other Indian source.

At the beginning of Islamic culture periods, Ebn-e Maghfa narrated and translated it from Persian to Arabic and named it "Kalila and Dimna". From Persian writing of Borzoyeh and Arabic translation of Ebn-e Maghfa, it was translated in any other language. In the era of Samanides, the first great Persian spokesman, Abou Abdollah Roudaki put the book of Ebn-e Maghfa in the modern poetry. After that the book was retranslated in Persian, until that Nasrollah Monshi was translated it in Persian another time. (Monshi, 2004).

The jealousy is the factor that seditious persons have greed in mundane goods and bear pride and overambition and obey the passion. Dimna was perished due to jealousy over Shanzieh.

Dimna went before lion due to overambition and reaching to his ambition and the lion incited to kill the cow. Dimna harbored the grudge against Shanzieh and planned to take vengeance; the first work performed by him was to gossip and slander in such a manner that he misrepresented the cow so poor and miserable and introduced the lion as oppressor and despot before cow that he deceived them with trick and deceit and caused the quarrel and sedition.

Jealousy, greed, obedience of passion, vengeance, overambition and slander are the factors caused the intrigue and instigation of the persons to take vengeance.

When the issue of vengeance is raised, the sedition will be excited automatically.

\section{Issue Expression}

In every country, a political system governs on a head of pyramid. In fact, this ruling organizes the affairs such as political, military, economic, social and cultural in that soci- 
ety along with a series of special objectives predetermined mostly.

Besides this ruling in lower levels, the political parties and political entities act in order to materialize the desires determined in system. Therefore, sometimes it is occurred that such objectives are materialized and this affair causes occurrence of the major problems in society. One of the major problems is the irregularity, disturbance and deterioration resulting in challenges which may be dragged the country to internal wars. The most important unpleasant result of this type of disorders is occurrence of sedition by seditious persons that the sedition is sparkled as result of several reasons such as jealousy, greed, vengeance and revenge and the fire of sedition is inflamed as result of perpetuity continuous and persistence of the leaders and surrounded the society. Therefore, for this reason, this article makes effort in determination and analysis of the reasons of sedition in Kalila and Dimna in reply to this question that what is the reason to be caused the sedition in Kalila and Dimna?

background research:

With regard to the performed research on determination and analysis of the reasons of sedition in Kalila and Dimna, we considered that no compiled and separated research work is performed with this approach, but concerning the word of sedition, several books, thesis and articles are written with political and social approach that it is not pointed to Kalila and Dimna in such works and engaged more in seditions of the beginning of Islam and seditions of the current years in Iran.

Therefore, this article has priority from this view. The compiled works include "intelligence and sedition in expression of leader of the revolution" written by Mohammad Daliri or "Naghshe Naghsh Bar Ab" written by Seyed Ali Khamenei and Sedition in view of Quran and Sedition Anatomy in view of Imam Ali written by Mostafa Akhoundi and works of other persons are written with approach of analysis of seditions of the beginning of Islam and sedition of the year 2009

\section{Research Objectives}

Overall Objective: Determination and Analysis of the sedition in Kalila and Dimna

Partial Objectives:

Introduction of another dimension of literature

Introduction of the sedition as a dangerous factor in any society

Introduction of Kalila and Dimna book more than before as a valuable work which may be researched the several, clean and virgin subjects in this work.

\section{Research Theory}

In case we study carefully the Kalila and Dimna, we can review the different reasons of sedition such as jealousy, greedy, vengeance, pride, revenge and passion abeyance. - Sedition:

Seditiousness among people is the constitutional and serious steps of the enemies for promoting the political and military objectives of them. Sedition causes deterioration of social relations and creation of dispersion and unreliability among persons of the society.

Most of the opportunists, self-executions and agents of the sedition are in a society who find the opportunity with creation of sedition in order to impose their thoughts to the society and made the persons of the society obedient to their thoughts and promoted in their favor and scattered the persons of the society and aggravated the conditions of the society and disturbed the minds.

During the several centuries, seditiousness has been used by opponents. In Islam religion, the opponents have benefi ed more from sedition for promoting their objectives and in case in Saghifeh theorem and differential of the Muslims in determination of substitute of Prophet (PBUH), one of the opportunists such as Abousophian throws it in raw greed in order to benefit the occurred position for bad objectives and causes disunion with supporting Imam Ali and destroys the new system of Islam. (Ghaedan, 2008: 1999-2001)

- Seditions and Social Events:

Seditions and social events are the affairs occurred in any society and better recognition from such seditions causes that the human remains more secure against it. The Muslim from non-Muslim is recognized in events of the society, otherwise until no events are occurred, all people of the society will be frank and sincere and when the sedition is occurred, the groups are separated from each other. So, seditions and social events are the means for testing the persons and societies.

- Sedition in Human Societies:

There are two types of sedition in human societies that we shall distinguish among them:

First type: Occurrence of the event makes the human on dilemma with different dimensions and such ways are designed in order to reach the destination according to the higher principles and rules and other ways were in contrary to others and leaded in inopportunity and misfortunes. Such seditions are one of the displays of God's wisdom and man motivations that it is pointed to it in Quran and one of the divine wills.

Second Type: The seditions are created by manlike animals in societies and families that made the realities plunged in darkness and protected from separation of right and void. The overall rule in this type of seditions called riot is that the humans spread the riot among them, even they are weak more, will expose more losses. Definition of riot is the disordered activities and motivations about events and realities having compound dimensions of right and void. (Allameh Jafari, 2005).

Reasons of Creation of Sedition in viewpoint of Lion:

Lion as the king of animal societies and first person of political system and with regard to full authority in view of thought and decision making and issuance of orders enjoys the special sensitiveness. The milk orders the search to Dimna about status of Shanzbeh, but in principle, he is in doubt from his decision on sending Dimna.

The lion hesitated and regretted sending Dimna and said with himself that I was not trustworthy in signing this judg- 
ment when a being oppressed in the sight of the innocent king and duration of pain and test is elongated or is suffering from net of injury and living hardship or destroyed all his assets and is deposed from any action determined for it and the famous naughty performed seditiousness in greed and avarice and tended less in good actions or the criminal tasted the punishment and their fans enjoyed the bestowment or they were a slight punishment of their partner and performed the overestimation in his favor or done a good service among superiors and his fans are preferred in beneficence and benevolence or the hostility outstripped on respect or had no reliability and trustworthy from religion and kindness or searched the benefit from the loss of the king or sought protection against hostility of the king and accepted them.

In reliance on such preliminaries before test and option, the king should not hurry in sending him to hostility and confidentiality in secrets of the mission and this Diman is the farsighted and has been the afflicted and obsolete before me for long time. If some disturbance remains in his heart, he will think on treachery and provoke the sedition and it is possible that he breeds the foe in his power and sense more than me and takes a delight in his conversation and service and tells my secrets to him. (Monshi, 2004, pages 71 and 72)

In this thinking of the lion, the reasons to create the sedition are expressed abstractly, but other reasons have effected which are completely related to thinking of the lion. 1- Jealousy:

The jealousy means malevolence and asking for deterioration of grace and prosperity of others. (Jalali Kondori 2003: Pages 184 and 185). Sometimes, this willing is linked together with benefiting the grace for oneself and occasionally, it is in company with destroying the grace of others (Tabarsi, 1993: 184).

The prophet, Mohammad (PBUH) said on jealousy that the jealousy destroys the benefactions as the fire burns and ruins the wood. (Haman, 184).

Then, one of the moral and spiritual features of the seditious persons is the jealousy. Jealousy is one of the sensual desires that the persons is involved in it and if it is searched for origin of this indisposition, we will find different factors such as selfishness, greed, avarice, timidity, perversion and deviation. (Alkhaledi, Bi Ta: 202).

If we go backward (beginning of Islam), we see that the Jewish seditious persons are jealous of the prophet, when they saw that the prophet, Mohammad is not Jewish the same as them and they couldn't bear it; although they knew that he is in the right and latest prophet of God or when they saw that others conducted to God and collected around the prophet (PBUH), so they were jealous of him and didn't believe in God and made their effort to mislead the Muslims.

Jadid Nabat, Bi Ta, Pages 123-134).

Therefore, the jealousy of Dimna causes that he couldn't bear the degree and prosperity of Shanzbe before lion. Although, Dimna was very clever and intelligent, but the jealousy is the reason for him to lose his patience and forbearance and blind and close his foresighted wisdom and do the action that he should not perform.
Because Dimna saw that the lion determines the matters to approach the cow and increase hourly in enhancing and selecting him and the hand of jealousy drags the vigilance in his eye and radiance of ager scatters the fire of emulation in order to awaken and get the sleep from him.

(Monshi 2004: 74)

Shanzbeh expresses the jealousy as the important factors:

Perhaps, my art causes this repugnance and the artists are dissipated under jealousy of the unskilled persons; (the nobles are under accusation of the jealousy) and unskilled persons exaggerate in disapproval of status of the artists and bring out his movements and pauses from meanness and in case they commit a crime and apparel of treachery to the person and consider the art as the prosperity and cause the adversity. (Haman, 104).

The lion was very uncomfortable because he killed the Shanzbeh, but Dimna explained his ugly and ill-looking action on exciting the fire of sedition against him

The sagacious kings would approach the person who has no intimacy to themselves for art and ethics and the person who likes themselves would keep away and in case they drink as well the unpleasant stingy drugs for profit and interest not for wish and passion and the finger is the ornament of the hand and tool for slip and seizing if the snake bites it, he shall carry him for revival and consider the difficulty of its bases. (Haman, 125)

In the thirteen chapter, the lion could satisfy the jackal with trouble to give him the ministry, but they didn't know that the persons around him will be jealous of him and begin the sedition and riot of government. His nearness and position was very heavy for relatives and agreed with each other in his eloquence and some days, they planned to select the person for stealing the meat that the lion put it for his lunch and hid it in the room of jackal. When the lion wants to eat it in another day, they said that we couldn't find it and the jackal was absent and one of them said that it is not remedied that they told me that the jackal carried the meat to his lodging. If the king orders that they shall search the meat in his lodging, my speaking is proofed and the special and public suppositions made sure. (Haman, 316317).

In narration of the most of the people, jealousy and jealousness are reproached and Amiralmomenin Ali (PBUH) narrated that

The jealousy is the method of ignoble men and enemies of the governments. (Tamie Amedi, 1960, Volume 1: 363).

2- Greed and Avarice:

Greed means intensity of interesting in or wanting something with seriousness and effort that is one of the bad morals and God forbids it in Quran and of course, it has the positive meaning.

The greediest people in the living are the Jews and polytheists in verse 96 of Baghareh Sura and most of the people don't become Muslim whatever you make effort and want it in verse 103 of Joseph Sura. Of course, the positive aspect in this verse based on greed and avarice of the prophet to conduct the polytheist is considered. (Khorramshahi, 1998, Volume 1: 922). 
In interpretation of the following sample, verse 96 of Baghareh Sura, it is said that:

This holy verse said about severe greed of them on monetary that you see them as the greediest people in life. Even more greedier than polytheists, more greedier in saving asset and property, more greedier in acquiring the World, more greedier in exclusiveness; whatever they are very interested in the world, any of them likes to live for a thousand year.

(Makarem Shirazi, 1996: volume 1: 101)

Greed and avarice of Dimna for approaching to lion was the factor to motivate him in order to kill the Shanzbeh and such action in any system is equal to occurrence of sedition and riot.

Of course, Dimna explains this action that when a person wants to return back to his previous position, he shall pay attention to three notes:

A: To keep the profit of statu

$\mathrm{B}$ : To bring out the passion from personality

$\mathrm{C}$ : To care of patient in acquiring goodness and removing badness. (Monshi 2006: 80).

Because, in fact, Dimna knows the Shanzbeh as the foe and considers any action as goodness for removing badness. Note:

Seditious persons promote to the extent in order to insult and venture the field of king or superior of the government and commit him in suspicion and weakness in intention and decision making in such a manner that Dimna declares in his rightness that I am hopeful to be fresh and leisure of heart and competency of lion and Shanzbeh goes to extreme and appoints the shortsightedness.

(Haman, 2001).

Of course, amongst, there are the persons to amend the system such as personality of Kalila was the sincere friend of Dimna and forbade him from this action and knew his unfortunate aftermath, but greed and avarice surrounded the rank and degree of Dimna that Kalila has no trust to amend it and tell to Dimna that your admire and being prideful in your judgment and excitement of degree of this delusive world are deceit and trick, but in its declaration, I thought it and waited for awakening from the sleep of the negligence. (Haman, 115).

Dimna declared that greed on wanting the degree weaken my opinion and made worthless your recommendations in my heart. (Haman, 142).

Greed and profanity is not only with respect to world rank, but it is possible to be greed on asset and property of the world and this issue puts the pigeons in a great test and sedition created by hunter.

Note: In here, the word of test and affliction is achieved from sedition, because the writer of book "Majmaolbahrein" believes that the sedition in Arab means affliction and test and originates from affliction until it shall be entered in fire to be pure. (Majmaolbahrein, Volume 6, page 291).

The hunter comes and drops the seed and lies in ambush for an hour and a tribe of pigeons come..., when they saw the seed, came down carelessly and are trapped totally. (Haman, 177).

Another sample of greed in mundane goods and difficulty in calamity and sedition is the donkey which is cheated by fox in greed of a comfortable life not once but twice and involved in fire of sedition and preyed by the lion

Fox went near the donkey and opened the way of conversation with him. The fox said that if listen to me, I carry you to the meadow that when the donkey hears this talking, the greed motivates him to bake the bread of the fox. (Haman, 255 and 256).

3- Vengeance and Revenge:

Nearness of Shanzbeh to the lion was to the extent that even the rank of ministership was given to him and this affair caused that Dimna keeps away less from attention of the lion and for this reason, the sense of vengeance and revenge in Dimna drags him in fire and he made his effort to pull aside the Shanzbeh by tricks.

Dimna said that I think that I attained my objective by tricks and made my effort under any aspect to remove him. (Haman, 79).

Note: It is to be mentioned that one of the ways to reach to the bad objectives is to use the stratagem and trick.

Dimna believes that whatever he performs by trick, he will not lose by force. (Haman, 81). It means that the base of works doesn't remain by nature and domination of friends. (Haman)

Another sample from the sense of vengeance and revenge is the king and Barahemeh. Because the king killed twelve thousand persons of Barahemeh as result of uncertain reasons in book and this affair caused that they harbored the grudge against king and followed the opportunity to interpret it and they accepted and gone aside and sat down in empty place and told another time that in this era, the king killed twelve thousand of us and at present, we were aware of his secret and obtained the root of his action that we could throw our revenge. (Haman, 351-352). Then, they interpreted incorrectly the dream of king in parallel with vengeance and revenge.

The kinds and leaders in any era shall keep away from revenge of others and pay attention to the aspects of the affairs with full discipline, because the revenge is the fir under ash. In case their request is not materialized or felt the sense of dangerous, they will kindle the fire of sedition.

When the revenge in heart is not excited, it is the kindled fire without firewood. Although it is not shown any effect, found the excuse and shown itself by indignation and fired the world and burnt it. (Haman, 295).

4- Pride and Dignity:

The pride comes from selfishness and insolence and originates from overambition and it means that selfishness and self-superiority and cause of pride and glory on each other and known itself as superiority. (Bandar Rigi, 2010, Pages 350 and 468). In persian

Hazrate Ali told to Malek Ashtar in his letter that:

Malek, please abstain to be selfishness and make sure of whatever occurs for you.

(Feizoleslam, 2003: 286).

When the human neglects the God, attention to oneself will replace from attention to God and see any goodness and completeness in oneself whether in appearance or inward. So, he is involved in selfishness (pride) and he considers 
himself as great for having excellence and prides himself. The selfishness causes that a person knows himself as superior and regards with contempt in them and fells a victim of pride and selfishness

Totally, the presidency and selfishness and all bad morals are originated from selfishness and the root of selfishness is negligence of God

One of the appearance signals of price and prejudice is that when a person says "me". Because Dimna hopes to return to his high degree and knows the high rank as his right and he became impudent due to this selfish and pride and sees himself as superior in policy and this is the signal of selfishness which is resulted in incorrect steps and will be leaded in sedition.

Because I am hopeful to be reached to my degree and be fresh that the freedom of my heart and goodness of lion is in it whether it is overdone in his abundance and pertained in his attention.

(Monshi, 2004: 80).

Of course, as it is pointed previously that Kelila is the sincere friend of Dimna and this is pointed the pride of Dimna to him and your pride admiration was obvious in his judgment. (Haman, 115).

Dimna involved in an artificial pride, so he deems stand himself as supreme in cleverness of thinking on others even lion.

\section{5- Tale-bearing and Backbiting:}

Tale-bearing means being a third person among two parties that he backbites from other person before another which is the basic of stimulation. One of the success reasons of each person - when in working area or in home is the trustworthy of persons. It is proved that if the third person becomes among two parties even with good intention, it is the agent to instigation of person with respect to other person in such a manner that Dimna backbites from cow before lion and complains the lion before cow, this tale-bearing leads in instigation of the parties and finally causes creating the sedition and killing the Shanzbeh.

Dimna said that how he could be healthy, when he is not the owner of his passion. Capturing by objective of others and always fearing his life and taking the attention of king and escape healthy, we don't have any, do we? (Haman, page 100).

Note: The lie is the factor to strengthen the backbiting. In case Dimna resorts to lie and tells that I heard from reliable that the lion told that Shanzbeh became fat and no need arises for him and I will motivate the wild for his meat. (Haman, 101) and continue that but complete fickleness causes that he performs as guilty and acts deceitful. The beginning of his conversation causes sweetness in life and end of it causes death. (Haman).

Ray said that I heard that Berahman who was as two sincere friends was killed as guiltless. (Haman, 157).

6- Instigation and Stimulation:

The stimulating talking of Dimna instigates the lion to kill the Shanzbeh. In fact, one of the disadvantage points of lion was non-thinking and farsightedness and it is the factor to be cheated soon and not aware of its aftermaths and weaken the asset and in case the accident occurs as great, the problem will happen and destroy the place of discipline and when the opportunity is finalized and the enmity became predominant. (Haman, page 96).

I feared that the wild agreed with him and motivated all against me, so in contrary to it sweets in hearts. (Haman, 98).

Usually, handing on prejudice and enthusiasm of the persons is a motivating factor.

Because Dimna is cheated the Lion and knows that the sedition is kindled and wants to see the cow and deteriorate him. (Haman, 100).

This feature is very unpleasant. Because, the people is more ignorant and fells him in battle and instigates the king for war in the action leaded in reconciliation. (Haman, 115).

Another sample in eighth narrative is about lion and cow on magpie, jackal and wolf as result of hungry and inability to make decision and arouse the lion against camel.

He went to the side and told another time that what is the position of this camel among us?

(Monshi, 2004; 107)

This affair shows that the seditious persons take steps to make sedition with co-thinking and companion in sedition and in head of this co-thinking, there is a thoughtful and leader brain that in here, the magpie found this degree and in any sedition and riot, the seditious persons think about their personal interests not for comfortably and easiness of others such as nations and innocent persons. The lion shall motivate him to break him and create the eating thing and receive something for our lunch. (Haman).

Finally, magpie went before lion and convicted him to design the map that not the lion accused of the contract breaching against camel and all hungers survive from hungry. At present, he fells in this trouble if we cannot submit our soul to others, we committed the profanity and the camel eats the sugar and performs kindness and tells one word and all wild dropped him and is devoured by them. (Haman, 109).

Another sample of motivation: it is came from monkey and turtle that when money and turtle became sincere friends, this action is unpleasant for the spouse of turtle and the sister of turtle as a stimulator and seditious kindles the fire of sedition and instigates the woman of turtle against his husband and the woman motivates the turtle on killing the monkey.

She made herself as patient in point of sister and requested from his husband to find the drug and turtle said that what is this drug to not find in this region, you tell me soon to find it and she answers me that this type of pain of womb and its cure is special for ladies and that is not recognized by any one except monkey. (Haman, 243), so, the love of lady governs and he follows for drug and knows that until the money doesn't fell in island, this objective is not materialized.

(Haman, 244).

7- Not paying attention to subordinates on behalf of the king:

The leaders told that the king shall pay attention to the workers and don't prevent them from his kindness that they are disappointed and intended to the enemies and not give grace to be wealthy soon and the interference influences his 
mind and imitates in the custom of God and he passed the days among fearing and victory, not bravery and disappointment. Not riot goes in him. Although the tail of scorpion is closed, but when it is opened, its sting is not cured.

(Haman, 93-94).

Note: All reasons addressed in this research as result of sedition such as jealousy, greed, vengeance, backbiting and instigation if we root precisely that one of the main reasons is the obedience of the passion. Therefore, any creative thought or type of obedience from passion is out of Quran and tradition of prophet which causes riot and discrete of the systems available in world.

So, innovations in a society are shown themselves through passions and selfishness. Because, it is normal that the innovations are submitted excellently and deceitfully to the societies which are finalize and fixed with reality of religion and keeping the tradition and activity of healthy mind and cause creation of ideas and personal interpretations and kindles of sedition and riot and grouping are started. (Allameh Jafari, 1997. volume 10: 108)

\section{CONCLUSION}

The sedition is a unenviable disorder in a society that has the several reasons including jealousy, greed, vengeance, price and backbiting and tale-bearing, less paying attention to the jurisdiction, instigation and stimulation that all of such reasons are created as result of obedience of passion in persons and Dimna is the obvious and certain case of cheated one that he fells in negligence as result of obedience from passion, not only cause for killing Shanzbeh which was the minister of lion, but he lost his soul in this way and even the court of the king involves in disorder and riot and when the fire is kindled, all persons related to this disorder are swallowed and killed.

\section{REFERENCES}

Holy Quran, Monshi, Nasrollah, 2004, translation of Kelila and Dimna written by Mojtaba Minovi, Tehran, Amirkabir, printing 25 .

Ghaedan, Asghar, 2008; Analysis on political positions of Ali ebne Abitaleb after death of prophet until murder of Osman, Tehran, Amirkabir.

Feizoleslam, Alinaghi, 2003; Nahjolabalagheh, Tehran, Faghih Publication, fifth printing

Allameh Jafari, Mohammadtaghi, 1997, description of Nahjolbalagheh, translation and interpretation of Nahjolbalagheh, Tehran, publication of Farhang Eslami, first printing.

Jalali Kondori, Soheila, 2003, recognition of the Jews, Tehran, publication of Farhang Eslami, second printing.

Tabarsi, Abouali Fazlebne Hassan, 1417GH, Elamolvari with Alamolhoda, Qom, Alebeitolehya institute.

Tabarsi, 1993; SH, Majmaolbayan in interpretation of Quran, introduction of Mohammadjavad Bolaei, Tehran, Naser Khosro, printing 18.

Alkhaledi, Jadid Nabat, Ali, Bita, analysis on performance of the Jews in prophecy era, Imam Khomeini Educational Research Institute, first printin

Khorramshahi, Bahaedin, 1998, Quran and Quran searching diploma, Tehran, Doustan-Nahid Publications, first printing.

Makarem Shirazi, Naser, 1996, selection of outstanding interpretation, Qom, Darolkotob Eslamieh publications, printing 13.

Tamimi Amedi, Abdolvahedebne Mohammad, 1960, 2001, GH, description of researcher, Jamaleddin Mohammad Khansari, introduction and correction and suspension of Mir Jalaleddin Hosseini Armavi, Tehran, Tehran University publication. 